\title{
ISOLATION OF SECONDARY METABOLITE COMPOUNDS AND ANTIBACTERIAL ACTIVITIES TESTS FROM HEXANE EXTRACT OF STEM BARK MELOCHIA UMBELLATA (HOUTT) STAPF VAR. DEGRABRATA $K$
}

\author{
USMAN USMAN ${ }^{1 *}$, MUH AMIR M${ }^{1}$, NUNUK HARIANI SOEKAMTO ${ }^{2}$, AHYAR AHMAD ${ }^{2}$, MAULIDIYAH MAULIDIYAH ${ }^{3 *}$ \\ ${ }^{1}$ PS-MPK and Department of Chemistry Education, FKIP University of Mulawarman, Jl. Kuaro, Gn. Kelua, Samarinda, Kota Samarinda \\ 75119 - Kalimantan Timur, Indonesia. ${ }^{2}$ Department of Chemistry Universitas Hasanuddin, Jl. Perintis Kemerdekaan Km. 10, Tamalanrea \\ Indah, Tamalanrea, Tamalanrea Indah, Tamalanrea, Kota Makassar - Sulawesi Selatan 90245, Indonesia. ${ }^{3}$ Department of Chemistry, \\ Faculty of Mathematics and Natural Sciences, Universitas Halu Oleo, Jl. HEA Mokodompit Kampus Baru UH0, Kendari 93232 - Southeast \\ Sulawesi, Indonesia. Email: sainusman@ymail.com/maulid06@yahoo.com
}

Received: 24 February 2018, Revised and Accepted: 05 May 2018

ABSTRACT

Objectives: This research aims to determine the content of secondary metabolite compounds and antibacterial activity of stem bark extract Melochia umbellata (Houtt) Stapf var. degrabrata.

Methods: M. umbellata stem bark was extracted by maceration using methanol solvent. Separation and purification were done by partitioning, fractionation with chromatography, and recrystallization. Antibacterial activity test of hexane extract and third isolate from the bark of $M$. umbellata was done by agar diffusion method against bacterium Bacillus subtilis, Staphylococcus aureus, Escherichia coli, and Pseudomonas aeruginosa.

Results: Phytochemical test showed that the hexane extracts of bark $M$. umbellata containing alkaloids and triterpenoids. Isolate D is a triterpenoid group compound, while FKa and FKb are steroid group compound. The hexane extract had the highest antibacterial activity against $B$. subtilis bacteria with inhibitory zone diameter $12.0 \mathrm{~mm}$. Isolate D has a weak inhibitory effect on all test bacteria. The highest diameters inhibition zone of isolated FKa compound against B. subtilis and S. aureus bacteria was $18.0 \mathrm{~mm}$ and $13.0 \mathrm{~mm}$, respectively. Whereas, the highest diameter inhibition of zone FKb compound against $B$. subtilis bacteria with inhibitory zone was $12.0 \mathrm{~mm}$.

Conclusion: The FKa compound from the bark of $M$. umbellata has the potential as antibacterial material because the compound is able to inhibit bacterial growth with $>14 \mathrm{~mm}$ obstacle zone, especially against $B$. subtilis bacteria.

Keywords: Antibacterial, Melochia umbellata, Triterpenoid, Steroid.

(C) 2018 The Authors. Published by Innovare Academic Sciences Pvt Ltd. This is an open access article under the CC BY license (http://creativecommons. org/licenses/by/4. 0/) DOI: http://dx.doi.org/10.22159/ajpcr.2018.v11i8.25464

\section{INTRODUCTION}

Plant species of Melochia umbellata is potential as antibacterial and belongs to the Sterculiaceae family. In Southern Sulawesi area, this plant is known by the traditional name of Paliasa. Paliasa consists of two species such as Kleinhovia hospita L. and Melochia umbellata (Houtt) Stapf and consisting of two varieties, i.e., M. umbellata (Houtt.) Stapf var. degrabrata (Fig. 1) and M. umbellata (Houtt) Stapf var. Visenia. This genus comprises herbs and shrubs distributed in the tropical and subtropical regions of the world. About seventy species occur in India and Indonesia, some of which are used in medicine [1]. These types of plants have long been used by communities in South Sulawesi as traditional medicine to treat hepatitis, liver, cholesterol, diabetes, dysentery, and hypertension [2]. Wonolita is a traditional name familiar used as a drug itching/scabies in Southeast Sulawesi region. Leaf powder from other species such as Sterculia setigera is used as a chronic cough medicine (tuberculosis) and HIV/AIDS [3]. Decoction of bark S. setigara is used also to treat asthma, bronchitis, diarrhea, and fever [4]. The decoction of leaves and roots of $M$. corcorifolia L. usually applied for treating dysentery [5].

The secondary metabolite compounds content in leaf tissues of M. umbellata is essential oils, terpenoids, alkaloids, flavonoids, steroids, and saponins [6,7]. It is also found a group of compounds; saponins, anthraquinones, and triterpenoids cycloartan [8]. Furthermore, the methanol extract of the bark of M. umbellata contains alkaloids, flavonoids, terpenoids, phenolic, and saponin $[9,10]$. Several secondary metabolite compounds which have been isolated from the M. umbellata plant and have useful biological activities such as the 3-acetyl-12-oleanen-28oat (Fig. 2a) compound has the highest inhibitory activity against the growth of bacteria Bacillus subtilis and fungal Candida albicans [10]. Stigmasterol compounds (Fig. 2b) are potentially as an antibacterial, compounds of 9.10-epoxy melochinone are toxic to Artemia salina, murine leukemia P-388 cells [11], and 6,6'-dimethoxy-4,4'-dihydroxy3',2'-furano-isoflavan. Furthermore, two new compounds are found on the tissue stem wood of M. umbellate (Fig. 3a) which is highly toxic to A. salina and murine leukemia cells P-388 as an Cleomiscosin (Fig. 3b), i.e., Walterion C and Cleomiscosin [12].

Exploration of secondary metabolite compounds on the tissue bark is potentially found new compounds that have biological activities in M. umbellata. Therefore, it is necessary to do further research to get information about secondary metabolite compound on the bark of M. umbellata and its bioactivity so that the use of plants as traditional medicine can be developed as a source of natural bioactive ingredients and as an antibacterial drug.

\section{EXPERIMENTAL}

\section{Equipment and materials}

Equipment used is glass wares commonly used in laboratory chemistry, column vacuum chromatography (CVC), column compression chromatography (CCC), gravity column chromatography (GCC), thin layer chromatography (TLC) plate (Kieselgel 60, F254 0,25 mm), chamber, micropipette, heater, evaporator, melting point, antibacterial and antifungal test, and UV lamp. The materials used in this research 


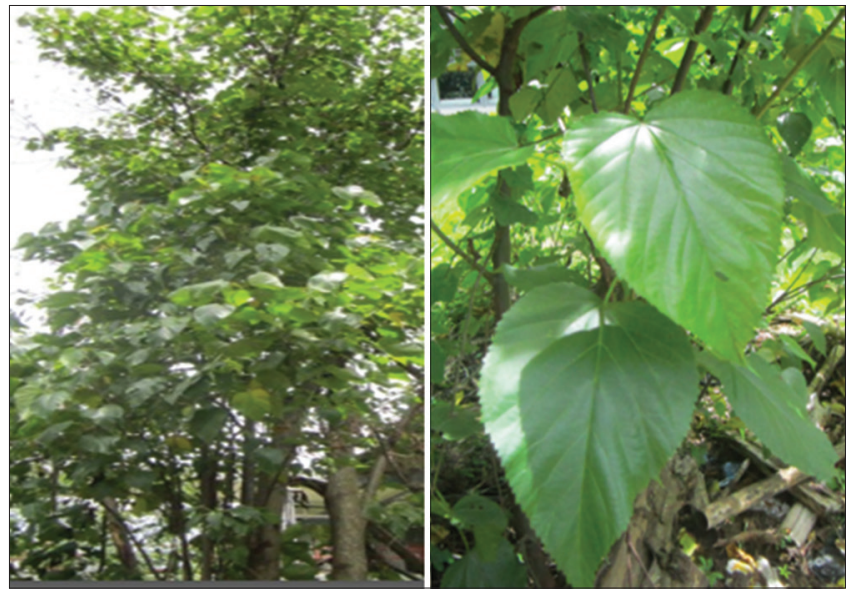

Fig. 1: Plant Melochia umbellata (Houtt) Stapf var. degbrata K

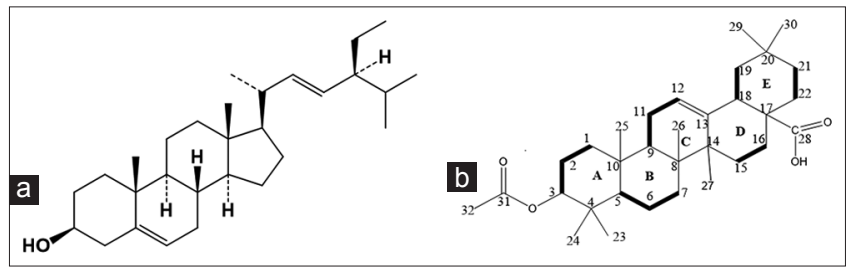

Fig. 2: Structure compounds; 3-acetyl-12-oleanen-28-oat (a), stigmasterol (b)

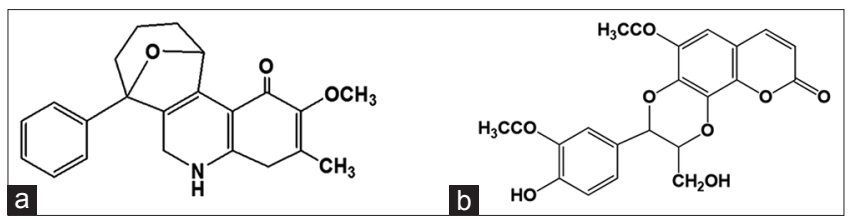

Fig. 3: Structure compounds: Walterion C (a), Cleomiscosin (b)

are samples of bark M. umbellata (Houtt) Stapf var. degrabrata with BO1912171 specimen number, organic solvent (n-hexane, chloroforom, ethyl acetate, acetone, and methanol), silica gel of size 60 (Brand, No. 7730, 7733, and 7734), dimethyl sulfoxide (DMSO) (Brand, No. Catalog of 802912), Amoxicillin, disc paper ( $6 \mathrm{~mm}$ ), pure bacterial culture of B. subtilis (ATCC 6633), Staphylococcus aureus (ATCC 25923), Escerechia coli (ATCC 25922), Pseudomonas aereginosa (ATCC 27853), $\mathrm{NaCl}$ physiological, and phytochemical reagents (alkaloids, flavonoids, steroids, triterpenoids, phenolic, and saponins).

\section{Preparation of sample}

M. umbellata bark samples used were collected from Tamalanrea Makassar, South Sulawesi. The sample is cleaned, cut into small pieces, then dried in the open air (at room temperature). Furthermore, the bark of M. umbellata is milled into powder with a size of 90 mesh.

\section{Isolation and purification}

M. umbellata bark samples of $5 \mathrm{~kg}$ were macerated with methanol solvent for $3 \times 24 \mathrm{~h}$. The obtained macerate was combined and evaporated the solvent using a rotary evaporator at a temperature of $40^{\circ} \mathrm{C}$ to obtain a condensed of methanol extract. The methanol condensed extract is further extracted by liquid-liquid partition using a solvent with an increased polarity level:hexane, chloroform, and ethyl acetate solvents. Each of the extract obtained was evaporated again using a rotary evaporator then weighed for rendemen determination, phytochemical tests, and antibacterial test. Isolation and purification of hexane extract was carried out using chromatographic techniques such as vacuum column chromatography, GCC, and plash column chromatography with suitable eluents. The isolate of the obtained compound was purified by recrystallization and chromatography. The isolate purity test obtained was done by analysis of TLC of three eluent systems and melting point test using melting point apparatus.

\section{Phytochemical test}

Phytochemical test of hexane extract bark of M. umbellata was done qualitatively. Phytochemical tests performed include alkaloid test using three types of reagents, i.e., Meyer, Wagner, and Dragendorff reagents; flavonoid test using concentrated $\mathrm{HCl}$ reagents with $\mathrm{Mg}$ metal, concentrated $\mathrm{H}_{2} \mathrm{SO}_{4}$, and $10 \% \mathrm{NaOH}$ solution; steroid and triterpenoid test using Lieberman-Burchard reagent; phenolic test using $\mathrm{FeCl}_{3}$ reagent; and saponin test using hot water and $2 \mathrm{~N} \mathrm{HCl}$ solution [13-15].

\section{Antibacterial activity test}

Preparation of media

A total of $23 \mathrm{~g}$ of nutrient agar powder (NA) in Erlenmeyer flask was dissolved in $1 \mathrm{~L}$ of distilled water sterile then heated to a complete dissolution. Furthermore, the medium NA in Erlenmeyer is clogged with cotton and covered with aluminum foil and sterilized in an autoclave at $120^{\circ} \mathrm{C}$ for $20 \min [16]$.

\section{Preparation of bacterial suspension test}

Test bacteria (bacteria B. subtilis, S. aureus, E. coli, and P. aeruginosa) were cultured on growth NA media tilted. Rejuvenation is done by transferring one use of the test bacteria into the media NA tilted then incubated at $37^{\circ} \mathrm{C}$ for $24 \mathrm{~h}$. Then, the bacteria test suspended by means of growing the bacteria test in physiological $\mathrm{NaCl}$ molten then incubated at $37^{\circ} \mathrm{C}$ for 24 $\mathrm{h}$ while shaken using a water bath rocked with a speed of $100 \mathrm{rpm}$ [17].

\section{Preparation of sample solution}

The concentration of the sample solution (hexane extract and third isolates) was used to test the antibacterial activity was $250 \mu \mathrm{g} / \mathrm{mL}$, $500 \mu \mathrm{g} / \mathrm{mL}, 750 \mu \mathrm{g} / \mathrm{mL}$, and $1000 \mu \mathrm{g} / \mathrm{mL}$.

\section{Testing of antibacterial activity}

Antibacterial activity was tested by the method of diffusion agar or KirbyBauer. As many as $1 \mathrm{~mL}$ of test bacterial suspension was inoculated into $200 \mathrm{~mL}$ Erlenmeyer flask that contains $100 \mathrm{~mL}$ of media NA. The mixture was homogenized using a shaker so that suspension is well blended and then poured into a Petri dish and let stand until the suspension mixture of the test bacteria in the Petri dish solidifies. Furthermore, a paper disc was prepared, dregs hexane extract samples and the third isolates by variation concentrations of $250 \mu \mathrm{g} / \mathrm{mL}, 500 \mu \mathrm{g} / \mathrm{mL}, 750 \mu \mathrm{g} / \mathrm{mL}$, and $1000 \mu \mathrm{mL}$ and then stand for $15 \mathrm{~min}$. The aseptic paper disc was placed on the surface of a Petri dish containing the test bacteria. Positive controls used were paper discs with chloramphenicol $(0.2 \mathrm{mg} / \mathrm{mL})$, the negative control used was paper disc dyed with DMSO 5\%. Petri dish was incubated at $37^{\circ} \mathrm{C}$ for $24 \mathrm{~h}$. Clearly, visible zones encoded with disc paper were indicated the presence of antibacterial activity. Furthermore, the clear zone formed was measured using the sliding term expressed by the size of the diameter inhibit zone.

\section{RESULTS AND DISCUSSION}

The result of extraction ( $5 \mathrm{~kg}$ sample) by means of maceration (solidliquid extraction) using methanol obtained extracts reddish brown as much as $396.5 \mathrm{~g}$. The extract $300 \mathrm{~g}$ was partitioned (Liquid-liquid extraction) using hexane solvent and obtained hexane extract of yellowish green as much as $36.10 \mathrm{~g}$. Subsequently, $30 \mathrm{~g}$ of hexane extract were separated by using CVC using eluent with ratio hexane:ethyl acetate (9:1) obtained 57 fractions. Based on the results of TLC analysis fractions that have similar stain profiles were combined to obtain 16 main fractions. The combined fraction is further fractionated by CCC and GCC with eluent; hexane, hexane:ethyl acetate ratio, ethyl acetate, and methanol. The fractionation was obtained by white crystals from $\mathrm{D}$ fraction and two other white crystals of $\mathrm{F}$ fraction, i.e. FKa and FKb compounds. The purity test of isolate D compound was carried out in a general way, i.e., TLC analysis using three eluent systems and the 
determination of melting point. TLC analysis showed one spot after being sprayed with serum sulfate and heated over the hot plate. The result of melting point measurement of compound D is $149-150^{\circ} \mathrm{C}$. Then, the phytochemical test of isolate D compound using LibermanBucher reagent gave brownish red color after addition of concentrated sulfuric acid and acetic anhydride indicating that the isolate of compound D is a triterpenoid group compound.

The purity test of FKa and FKb isolate compounds was carried out in the same way as purity test of compound D. The result of TLC analysis of FKa and $\mathrm{FKb}$ isolate compounds was using eluent of hexane:ethyl acetate (7:3), showing single spot. The melting point measurement of isolate $\mathrm{FKa}$ and $\mathrm{FKb}$ compounds was $115-117^{\circ} \mathrm{C}$ and $184-185^{\circ} \mathrm{C}$, respectively. Phytochemical test of isolates FKa and FKb compounds was prepared using Liberman-Bucher reagent with the color of turquoise blue. This shows that both isolates are steroid group compounds. The weight of the hexane extract and the third isolates obtained from the bark of $M$. umbellata is presented in Table 1 .

Phytochemical tests were performed to determine the presence of secondary metabolite group compounds contained in plants. The phytochemical test result of hexane extract and the three isolate compounds from M. umbellata bark can be shown in Table 2 .

Table 1: Weight of the hexane extract and the three isolates from the bark of $M$. umbellata

\begin{tabular}{lll}
\hline No. & Type extract/isolate compounds & Weight (g) \\
\hline 1 & Hexane extract & 36.1000 \\
2 & Isolate compounds D & 0.0182 \\
3 & Isolate compounds FKa & 0.0204 \\
4 & Isolate compounds FKb & 0.0176 \\
\hline M. umbellate: Melochia umbellata
\end{tabular}

Based on the phytochemical tests results (Table 2) as presented that the hexane extract contains alkaloid and triterpenoids group compounds. The isolate of compound D contains triterpenoid. FKa and $\mathrm{FKb}$ contain steroid group compound. Flavonoids, polyphenols, and saponins were not identified in the hexane extract and the third isolates of the compound. Previous research has been reported that the methanol extract from the bark of $M$. umbellata contains alkaloids, flavonoid, phenolic, triterpenoid, and saponin compounds [10]. Uddin et al. reported that $M$. umbellata contains essential oil compounds, triterpenoids, alkaloids, and flavonoids [7]. Other research from Melochia corchorifolia L (Sterculiaceae) is known to contain alkaloid group compounds, terpenoids, steroids, phenolic compounds, flavonoids, and glycosides [18]. Then, the stemwood tissue of $K$. hospita (Sterculiaceae) is known to contain triterpenoid group compounds.

Tables 3-5 show the statistical analysis results of hexane extract and three isolates from M. umbellata stem bark. Table 3 explained that the alkaloids compound using Meyer and Wagner tests give the information of $\mathrm{N}$-Hexane extract is a positive result (one extract). Table 4 shows that the phytochemical test steroids/triterpenoids LB compounds in $\mathrm{N}$-hexane, Isolate $\mathrm{Fka}$, and $\mathrm{FKb}$ (three extracts) give the positive and negative responses. Meanwhile, Table 5 shows the negative responses in 5 photochemical tests (alkaloids, flavonoids, steroids/triterpenoids LB, phenolic, and saponin) where the N-hexane extract, isolate compounds $\mathrm{D}$, compounds $\mathrm{FKa}$, and compounds $\mathrm{FKb}$. In short, the positive, positive and negative, then negative tests results explain that one extract, three extracts, and four extracts, respectively.

Phytochemical content such as alkaloids, flavonoids, tannins, phenols, saponins, and some other aromatic compounds is secondary metabolite compounds of plants that play an important role in the defense mechanism of microorganisms against insect and other herbivorous disorders. The presence of class compounds such as phenols, alkaloids,

Table 2: Phytochemical test results of hexane extract and three isolates from M. umbellata stem bark

\begin{tabular}{|c|c|c|c|}
\hline No & Phytochemical test & Extract and isolate & Information \\
\hline \multirow[t]{13}{*}{1} & Alkaloids & & \\
\hline & Meyer test & N-Hexane extract & Orange precipitate is formed $(+)$ \\
\hline & & Isolate compounds D & $(-)$ \\
\hline & & Isolate compounds FKa & $(-)$ \\
\hline & & Isolate compounds FKb & $(-)$ \\
\hline & Dragendorff's test & N-Hexane extract & No precipitation (-) \\
\hline & & Isolate compounds D & $(-)$ \\
\hline & & Isolate compounds FKa & $(-)$ \\
\hline & & Isolate compounds $\mathrm{FKb}$ & $(-)$ \\
\hline & Wagner test & $\mathrm{N}$-Hexane extract & White precipitate is formed (+) \\
\hline & & Isolate compounds D & $(-)$ \\
\hline & & Isolate compounds FKa & $(-)$ \\
\hline & & Isolate compounds FKb & $(-)$ \\
\hline \multirow[t]{3}{*}{2} & Flavonoids & N-Hexane extract & $(-)$ \\
\hline & & Isolate compounds FKa & $(-)$ \\
\hline & & Isolate compounds FKb & $(-)$ \\
\hline \multirow[t]{4}{*}{3} & Steroids/ & $\mathrm{N}$-Hexane extract & $(-/+)$ \\
\hline & triterpenoids LB & Isolate compounds D & $(-)$ \\
\hline & & Isolate compounds FKa & $(+/-)$ \\
\hline & & Isolate compounds FKb & $(+/-)$ \\
\hline \multirow[t]{4}{*}{4} & Phenolic & N-Hexane extract & $(-)$ \\
\hline & & Isolate compounds D & $(-)$ \\
\hline & & Isolate compounds Fka & $(-)$ \\
\hline & & Isolate compounds FKb & $(-)$ \\
\hline \multirow[t]{4}{*}{5} & Saponin & $\mathrm{N}$-Hexane extract & $(-)$ \\
\hline & & Isolate compounds D & $(-)$ \\
\hline & & Isolate compounds Fka & $(-)$ \\
\hline & & Isolate compounds FKb & $(-)$ \\
\hline
\end{tabular}

Information: (+): Positve, (-): Negative, M. umbellata: Melochia umbellata 
flavonoids, tannins, saponins, and steroids in the extract may act as an antimicrobial [19].

Antibacterial activity can be determined by detecting the inhibit zone (clear zone) on the bacteria growth test. It is shown by the extract and the three isolates encapsulated in the solid paper. The results showed

Table 3: Phytochemical positive test results of hexane extract and three isolates from $M$. umbellata stem bark

\begin{tabular}{llll}
\hline No & $\begin{array}{l}\text { Phytochemical } \\
\text { test }\end{array}$ & $\begin{array}{l}\text { Extract and } \\
\text { isolate }\end{array}$ & Information \\
\hline 1 & $\begin{array}{l}\text { Alkaloids } \\
\text { Meyer test }\end{array}$ & N-Hexane extract & $\begin{array}{l}\text { Orange } \\
\text { precipitate is } \\
\text { formed (+) } \\
\text { White precipitate } \\
\text { is formed }(+)\end{array}$ \\
\hline
\end{tabular}

M. umbellata: Melochia umbellata

Table 4: Phytochemical positive and negative test results of hexane extract and three isolates from M. umbellata stem bark

\begin{tabular}{llll}
\hline No & $\begin{array}{l}\text { Phytochemical } \\
\text { test }\end{array}$ & $\begin{array}{l}\text { Extract and } \\
\text { isolate }\end{array}$ & Information \\
\hline 1 & $\begin{array}{l}\text { Steroids/ } \\
\text { triterpenoids LB }\end{array}$ & N-Hexane extract & $(-/+)$ \\
& & $\begin{array}{l}\text { Isolate } \\
\text { compounds FKa }\end{array}$ & $(+/-)$ \\
& & $\begin{array}{l}\text { Isolate } \\
\text { compounds FKb }\end{array}$ & $(+/-)$ \\
& &
\end{tabular}

M. umbellata: Melochia umbellata hexane extract, and three isolates from the $M$. umbellata bark were able to inhibit the bacteria growth test. The mean inhibitory zone diameter which is a test of antibacterial activity can be shown in Table 3 .

Table 3 shows that hexane extract at a concentration of $1000 \mathrm{ppm}$ has an inhibitory effect on the bacterial growth of $B$. subtilis and $S$. aureus with inhibitory zone diameter were 12.0 and $10.4 \mathrm{~mm}$, respectively. Resistance to the growth of $E$. coli bacteria is relatively weak with a diameter of $8.0 \mathrm{~mm}$ inhibition zone. Isolate D compound showed inhibitory to growth of $B$. subtilis bacteria with $9.0 \mathrm{~mm}$ inhibitory zone diameter at $1000 \mathrm{ppm}$ concentration and included in the weak category. Fka compound isolated in concentration of $1000 \mathrm{ppm}$ had the highest activity against $B$. subtilis bacteria with diameter zone is $18.6 \mathrm{~mm}$ whereas the $S$. aureus, $E$. coli and $P$. aeruginosa bacteria with inhibitory zone diameter was $13.4 \mathrm{~mm}, 11.00 \mathrm{~mm}$, and $7.2 \mathrm{~mm}$, respectively.

The isolate compounds Fkb have moderate high activity against $B$. substilis and $S$. aureus bacteria with inhibition diameter zone of $13.0 \mathrm{~mm}$ and $11.5 \mathrm{~mm}$. Whereas the activity against E. coli and $P$. aureginosa bacteria have low activity with inhibition diameter zone of $8.0 \mathrm{~mm}$ and $7.0 \mathrm{~mm}$.

In general, hexane extract, $\mathrm{FKa}$, and $\mathrm{FKb}$ compound isolate from these plants showed the inhibitory effect against B. subtilis, $S$. aureus, and E. coli bacteria at a concentration of $1000 \mathrm{ppm}$. At concentrations below $1000 \mathrm{ppm}$, the inhibitory power is demonstrated by the hexane extract, and the two isolates of the compound on the growth of test bacteria are getting weaker or even showing no inhibitory or inactivity. The results of this study are supported by other research showing that hexane extract from $M$. umbellata leaves has the highest inhibition of growth of $S$. aureus bacteria with a diameter of the inhibitory zone of $11.45 \mathrm{~mm}$ at a concentration of $2500 \mathrm{ppm}$, while the ethyl acetate extract has the highest inhibitory on the growth of $S$. dysenteriae bacteria with a diameter of the inhibitory zone of $17.70 \mathrm{~mm}$ [20]. Other research reported that at a concentration of $1000 \mu \mathrm{g} / \mathrm{mL}$, hexane extract, methanol, and 3-acetyl-12-oleanene-28-oic acid compound showed the highest inhibition of $B$. subtilis bacteria and $C$. albicans fungi. Based on Ridhay et al. that the ethyl acetate extract from stem bark of M. Umbellata showed the highest inhibitory resistance

Table 5: Phytochemical positive and negative test results of hexane extract and three isolates from M. umbellata stem bark

\begin{tabular}{|c|c|c|c|}
\hline No & Phytochemical test & Extract and isolate & Information \\
\hline \multirow[t]{11}{*}{1} & Alkaloids & & \\
\hline & Meyer test & Isolate compounds D & $(-)$ \\
\hline & & Isolate compounds FKa & $(-)$ \\
\hline & & Isolate compounds FKb & $(-)$ \\
\hline & Dragendorff's test & N-Hexane extract & No precipitation (-) \\
\hline & & Isolate compounds D & $(-)$ \\
\hline & & Isolate compounds FKa & $(-)$ \\
\hline & & Isolate compounds $\mathrm{FKb}$ & $(-)$ \\
\hline & Wagner test & Isolate compounds D & $(-)$ \\
\hline & & Isolate compounds $\mathrm{FKa}$ & $(-)$ \\
\hline & & Isolate compounds FKb & $(-)$ \\
\hline \multirow[t]{4}{*}{2} & Flavonoids & N-Hexane extract & $(-)$ \\
\hline & & Isolate compounds D & $(-)$ \\
\hline & & Isolate compounds $\mathrm{FKa}$ & $(-)$ \\
\hline & & Isolate compounds FKb & $(-)$ \\
\hline \multirow{3}{*}{4} & & Isolate compounds D & $(-)$ \\
\hline & & Isolate compounds Fka & $(-)$ \\
\hline & & Isolate compounds FKb & $(-)$ \\
\hline \multirow[t]{4}{*}{5} & Saponin & N-Hexane extract & $(-)$ \\
\hline & & Isolate compounds D & $(-)$ \\
\hline & & Isolate compounds Fka & $(-)$ \\
\hline & & Isolate compounds FKb & $(-)$ \\
\hline
\end{tabular}

M. umbellata: Melochia umbellata 
Table 6: Results of antibacterial activity test of hexane extract and the three isolate compounds from stem bark of M. umbellata (Houtt) Stapf var. degrabrate

\begin{tabular}{|c|c|c|c|c|c|c|}
\hline \multirow[t]{2}{*}{ No } & \multirow[t]{2}{*}{ Extract/isolate } & \multirow[t]{2}{*}{ Const. (ppm) } & \multicolumn{4}{|c|}{ Inhibition zone diameter (mm) } \\
\hline & & & B. subtilis & S. aureus & E. coli & P. aeruginosa \\
\hline \multirow[t]{2}{*}{1} & \multirow[t]{2}{*}{ Hexane extract } & 1000 & 12.0 & 10.4 & 8.0 & $\mathrm{NI}$ \\
\hline & & 250 & 7.0 & 8.0 & 8.0 & $\mathrm{NI}$ \\
\hline \multirow[t]{3}{*}{2} & \multirow[t]{3}{*}{ Isolate compounds D } & 1000 & 9.0 & NI & NI & $\mathrm{NI}$ \\
\hline & & 500 & 8.0 & $\mathrm{NI}$ & $\mathrm{NI}$ & NI \\
\hline & & 250 & 8.5 & $\mathrm{NI}$ & $\mathrm{NI}$ & NI \\
\hline \multirow[t]{3}{*}{3} & \multirow[t]{3}{*}{ Isolate compounds FKa } & 1000 & 18.6 & 13.4 & 11.0 & 7.2 \\
\hline & & 500 & 15.8 & 11.2 & 9.4 & 7.0 \\
\hline & & 250 & 11.4 & 9.3 & 8.8 & 7.0 \\
\hline \multirow[t]{3}{*}{4} & \multirow[t]{3}{*}{ Isolate compounds $\mathrm{FKb}$} & 1000 & 13.0 & 11.5 & 8.0 & 7.0 \\
\hline & & 500 & 11.2 & 9.5 & 7.8 & 7.2 \\
\hline & & 250 & 9.8 & 10.0 & 7.0 & 7.2 \\
\hline 5 & $\mathrm{PC}(+)$ & 25 & 25.0 & 23.7 & 20.3 & 21.2 \\
\hline 6 & NC $(-)$ & & NI & NI & $\mathrm{NI}$ & $\mathrm{NI}$ \\
\hline
\end{tabular}

PC (positive control): Chloramphenicol, NI: Not inhibit, NC (negative control): DMSO, DMSO: Dimethyl sulfoxide, B. subtilis: Bacillus subtilis, S. aureus:

Staphylococcus aureus, E. coli: Escherichia coli, p. aeruginosa: Pseudomonas aeruginosa

to $S$. aureus bacteria and Aspergillus niger fungi with each inhibition zone $>14 \mathrm{~mm}$ [11].

Each type of bacteria has a different sensitivity to antibacterial substances because each bacterium has a different cell wall structure so that the antibacterial effect on bacteria is also different. Gram-positive bacteria such as $S$. aureus and B. subtilis have only one layer containing peptidoglycan, thin-filmed tea picric acid, and the uric acid while Gramnegative bacteria have layers outside the cell wall containing 5-10\% peptidoglycan, in addition to proteins, lipopolysaccharides (LPS), and lipoproteins. Gram-negative bacteria such as E. coli and P. aureginosa bacteria have two layers of lipid (lipid bilayer) called LPS layer so that antimicrobial substances more difficult to penetrate into the cell wall of bacteria Gram-negative bacteria [21].

According to Wattimena that the act as an antimicrobial if such compound provides an average of inhibition zone $>14 \mathrm{~mm}$. Based on the results of the antibacterial test, it can be concluded that FKa compound isolates from $M$. umbellata plant have potential as antibacterial because the compound is able to inhibit bacterial growth with a diameter of inhibit zone $>14 \mathrm{~mm}$, especially against bacterium $B$. subtilis [22].

\section{CONCLUSION}

The hexane extract of the stem bark (M. umbellata) contains alkaloid and triterpenoid group compounds, isolate D compound contains triterpenoid group compounds, as well as isolates FKa and FKb compound contain steroid group compounds. Isolate Fka compound has a strong inhibitory effect on the growth of $B$. subtilis bacteria with $18.6 \mathrm{~mm}$ inhibition zone diameter and potentially as an antibacterial compound.

\section{ACKNOWLEDGMENTS}

Our gratitude goes to the Head of Microbiology Laboratory, Faculty of Pharmacy, Hasanuddin University who has provided facilities to conduct this research and Head and Staff of Herbarium Bogoriense, Botanical Research and Development, for Biological Research and Development (LIPI) Bogor, which has identified the specimens of this plant.

\section{AUTHOR'S CONTRIBUTIONS}

The contributions of the author for this paper to describe the traditional plant (M. umbellata) from South Sulawesi-Indonesia were potentially for the medicinal drug (antibacterial).

\section{REFERENCES}

1. De S, Dey A, Babu AM, Aneela S. In vitro anthelmintic activity of aqueous and methanolic extracts of Oldenlandia umbellata. Int J Pharm
Pharm Sci 2014;6:94-5.

2. Ahmad F, Soekamto NH, Firdaus. Phytochemical and toxicity assay extract ethyl acetate of Melochia umbellata (Houtt) Stapf. Var. visenia by brine shirmp lethality test method. Ind J Chem Res 2017;4:378-81.

3. Babalola IB, Adelakun EA, Wang Y, Shode FO. Anti-tuberculosis activity of Sterculia setigera del., leaves (Sterculiaceae). J Pharm Phytochem 2012;1:17-23.

4. Igoli JO, Ogaji OG, Tor-Anyiin TA, Igoli NP. Medicinal practices among the igede people of Nigeria Part II. Afr J Complementary Altern Med 2005;2:134-52.

5. Shanmugam S, Kalaiselvan M, Selvalumar P, Suresh K, Rajendran K. Ethnomedicinal plants used to cure diarrhoea and dysenteryin shivangangai district of Tamil Nadu, India, Int J Res Ayyuveda Pharm 2011;2:991-4

6. Uddin G, Rauf A. Phytochemical screening and biological activityof the aerial parts of Elaeagnus umbellata. Sci Res Essays 2012;7:3690-4.

7. Aeni HM, Soekamto NH, Firdaus. Phytochemical and toxicity assay extract chloroform of stem bark of Melochia umbellata (Houtt) Stapf. Var. visenia by brine shirmp lethality test method. Ind J Chem Res 2017:4:382-5.

8. Netala VR, Ghosh SB, Bobbu P, Anitha D, Tartte V. Triterpenoid saponins: A review on biosynthesis, applications, and mechanism of their action. Int J Pharm Pharm Sci 2015;7:24-8.

9. Soekamto NH, Usman H, Ahmad A. Toxicity and antimicrobial activity from extract and oleanan derivative compounds of the bark Melochia umbellate (Houtt) stapf var. degrabrata K. Int J Pharm Bio Sci 2014;5:231-8.

10. Soekamto NH, Usman H, Ahmad A. The Potential of Secondary Metabolites Compound From Methanol Extract of Stem Bark Melochia umbellate (Houtt) Stapf var Degrabrata As Antibacterial. Book of Abstracts, International Conference On Mathematics, Sciences, Technology, Education And Their Aplication (ICMSTEA); 2014. p. $1-178$.

11. Ridhay A, Noor A, Soekamto NH, Harlim T. A stigmasterol glycoside from the root wood of Melochia umbellata (Houtt) stapf var. degrabrata K. Ind J Chem 2012:12:100-3.

12. Alfian NE, Soekamto NH, Altena IV, Syah YM. Waltherione C and cleomiscosin from Melochia umbellate var. degrabrata K. (Malvaceae). biosynthetic and chemotaxonomic significance. Biochem Syst Ecol 2014;55:358-361.

13. Edeoga HO, Okwu DE, Mbaebie BO. Phytochemical constituents of some Nigerian medicinal plants. Afr J Biotechnol 2005;4:685-8.

14. Patil MB, Khan PA. Primary phytochemical studies of catunaregam spinosa (Thunb) triven for secondary metabolites. Int J Pharm Bio Sci 2017;8:320-3.

15. Joshi N, Bhatt S, Dhayani S, Nain J. Phytochemical screening of secondary metabolites of Argemone mexicana Linn. flowers. Int J Pharm Bio Sci 2013;5:144-7.

16. Gowri SS, Vasantha K. Solvent based effectiveness of antibacterial and phytochemical derivatized from the seeds of Harpullia arbarea (Blanco) Radlk (Sapindaceae). PG Res Dep Bot 2009;13:99-101. 
17. Cahyana AH, Suwarso WP, Nurdin M. Isolation and structure elucidation of eumitrin A1 from lichen Usnea blepharea Motyka and its cytotoxic activity. Int J PharmTech Res 2015;8:782-9.

18. Harini V, Vijayalakshmi M, Sivaraj C, Arumugam P. Antioxidant and anticancer activities of methanol extract of Melochia corchorifolia L. Int J Sci Res 2017;6:1310-6.

19. Bonjar GH, Nik AK, Aghighi S. Antibacterial and antifungal survey in plants used in indigenous herbal-medicine of south east regions of Iran. J Biol Sci 2004;4:405-12.
20. Wulur S, Firdaus, Natsir H, Soekamto NH. Study of compounds from extract of Melochia umbellate (Houtt) Stapf. degrabrata K (paliasa) leaves that has potential as antibacterial. J Ind Chem Acta. 2015;8:1-8.

21. Madigam MT, Martinko JM, Stahl DA, Clark DP. Biology of Microorganism. 13 $3^{\text {th }}$ ed. San Fransisco: Pearson; 2012.

22. Sabarwati SH, Safutra E, Nurdin M. Atranorin secondary metabolite from lichen Usnea sp. and its antibacterial activity. Int J Pharma Bio Sci 2016;7:159-69. 